\title{
NefERTITI LÄNGTAR HEM
}

Herbert Ganslmayr, framsynt direktör för Bremens etnografiska Übersee-Museum, var under en följd av år ordförande i ICOMs Advisory Committee och aktiv i ICME, den internationella kommittén för etnografiska museer. Återförandeönskemålen diskuterades då som bäst inom Unesco och Ganslmayr argumenterade kraftfullt för ICOMs roll i deras praktiska förverkligande. Särskilt drev han ömsesidighetsprincipen i förhållandet mellan tredje världens och Europas museer. I boken Nofretete will nach Hause. Europa - Schatzhaus der dritten Welt som kom ut 1984 skrev han några av de fallstudier som blev en verkningsfull plädering för de rättmätiga kraven på ett återlämnande av det kulturarv som under långa år av kolonial exploatering hopats i Europas etnografiska museer. Unescos utredning av restitutionsfrågan ledde fem år senare till den resolution som fastslog alla samhällens primära rätt till sitt kulturarv. Återförandefrågor togs upp som huvudtema när Skandinaviska Museiförbundet höll sitt 33:e möte i Reykjavik 2002. Nordisk Museologi har fått förtroendet att publicera de nio huvudföredragen, som sammantagna ger en god översikt av hur de återförandekrav som aktualiserats mellan nordiska länder tillgodosetts. Den klassiska nordiska återförandefrågan gäller 'håndskriftsagen', dvs. de isländska medeltida manuskript som sedan 1700-talet befunnit sig i Danmark, tack vare den idoge samlaren Arni Magnusson. Under Islands gradvisa frigörelse från Danmark har vid olika tidpunkter manuskriptens återbördande till Island krävts som en omistlig del av islänningarnas kulturarv. Hur frågan tett sig ur isländsk synpunkt behandlas av Vésteinn Ólason och ur dansk synpunkt av Birgitte Kjer. Ett näraliggande problem var isländska föremål i danska museer, särskilt Nationalmuseet i Köpenhamn. Om detta skriver Torbjörg Torgrimsdóttir. Liknande bilaterala problem inom den danska maktsfären gäller Grönland och Färöarna. Hur de lösts behandlar Emil Rosing resp. Arne Thorsteinsson.

Men också den över åren rörliga danska sydgränsen mot Slesvig har lett till kulturarvstvister som började redan i samband med gränskrigen under åren 1848-1864. De intrikata återförandeturerna klarläggs av Inge Adriansen.

Stor uppmärksamhet har under senare år ägnats samernas äganderätt till sin egen kultur och sitt materiella kulturarv. Hur situationen ter sig för det unga samiska museet, 'SIIDA', i Rovaniemi beskriver Tarmo Jomppanen. Samerna får också särskilt 
2 beaktande i den norska rapport som lagts fram av en kommitté under Jon Birger

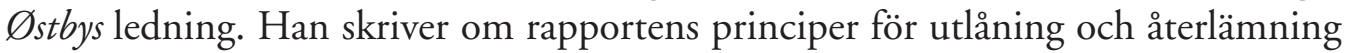
av samlingar som ska vägleda norska museer.

Slutligen reflekterar Monika Minnhagen-Alvsten vid svenska riksantikvarieämbetet kring några konkreta återförandeärenden. Sammantagna ger föredragen en ljus bild av hur antagonistiska konfrontationer med tiden genom förhandlingar kunnat upplösas i samförstånd och förståelse, ljus - om man jämför med den pågående bittra striden om Partenonfrisen i British Museum. Har förutsättningen varit den gemensamma kultur som de nordiska ländernas sammanflätade historia skapat - trots att den rymt många perioder av krigiska konflikter och gränstvister?

David Anderson, den i nordiska museikretsar välkände ledaren för undervisningsavdelningen vid Victoria \& Albert-museet i London, har sedan länge arbetat för en förnyelse av museet. Resultatet är det s.k. Spiral-projektet för en tillbyggnad ritad av Daniel Libeskind. David Anderson rapporterar i numrets andra del tillsammans med fyra medarbetare om projektets läge. Själv formulerar han i tre texter en museivision som just nu făr stöd i de kultur- och bildningspolitiska idéer som blir alltmer framträdande i Tony Blairs England. De fysiska aspekterna behandlas av Gwyn Miles, Daniel Libeskind och Cecil Balmond, de museologiska, av David Anderson, och Jane Pavitt.

Per-Uno Agren

\section{Return of Cultural Property}

The Scandinavian Museums Association was founded in 1915, the purpose being to promote personal contacts and the exchange of professional experience within the museum community. Originally sections were formed in Denmark, Norway and Sweden; further sections were added in 1923 in Finland, in 1929 in Iceland and in 1985 in the Faroe Islands. The Association has arranged meetings at irregular intervals, after a lapse during the war years 1939 to 1945 , meetings were resumed and took place every second or third year in the various countries. The $33 \mathrm{rd}$ meeting was held in 2002 in Reykjavík. Its theme, 'the restitution of cultural property to the countries of origin', was the focus of 9 papers with ensuing discussions. Nordisk Museologi in cooperation with the Association is happy to present the papers in the first part of this issue. They are summarised on p. 58 . 